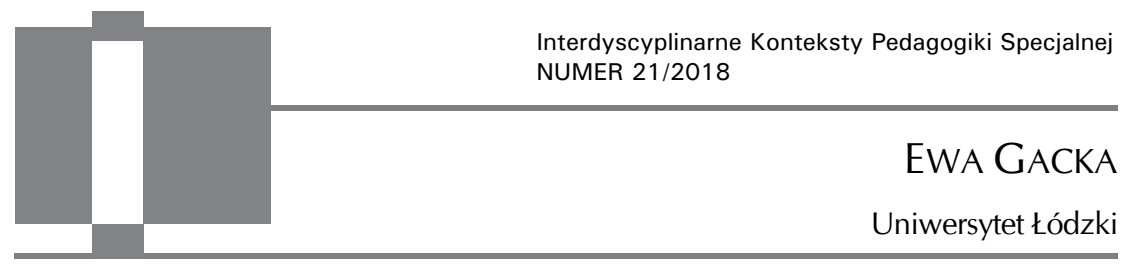

\title{
Zapobieganie nieprawidłowościom w rozwoju artykulacji u dzieci w wieku niemowlęcym i poniemowlęcym
}

\begin{abstract}
Ewa Gacka, Zapobieganie nieprawidtowościom w rozwoju artykulacji u dzieci $w$ wieku niemowlecym i poniemowlecym [The prevention of disorders in the articulation development of children at the infancy and post-infancy stages]. Interdyscyplinarne Konteksty Pedagogiki Specjalnej, nr 21, Poznań 2018. Pp. 125-140. Adam Mickiewicz University Press. ISSN 2300-391X. DOI: https://doi.org/10.14746/ ikps.2018.21.07

The development of speech, including articulation, begins at birth, whereas its biological foundations are shaped already during the foetal development. The acquisition of linguistic competence (including phonetic and phonological) is determined by various factors. The article is dedicated to the preventive care in regard to speech disorders of children. The author primarily focuses on the primary activities of speech/articulation (articulation is one of the aspects of speech, and the primary activities of speech may be considered, simultaneously, as primary in comparison to articulation). The article presents activities that prevent the occurrence of articulation development disorders, directed at infants and post-infancy children. DOI: https:/ / doi.org/10.14746/ikps.2018.21.06
\end{abstract}

KEY WORDS: articulation disorders, preventive speech therapy, infancy and postinfancy 


\section{Nabywanie kompetencji fonetyczno-fonologicznej w ontogenezie}

W systemie językowym wyróżnić można kilka podsystemów, m.in. fonologiczny, dotyczący dźwiękowej strony języka. Jak podaje Józef Porayski-Pomsta, ,termin język dziecka odnosi się do procesów przyswajania (akwizycji) i znajomości systemu językowego. Na poziomie świadomościowo-wykonawczym odpowiada mu pojęcie kompetencji językowej"1. W niniejszym artykule za Edwardem Łuczyńskim przyjęto, że kompetencja językowa to „(...) zdolność swobodnego posługiwania się danym językiem, możliwość porozumiewania się w nim i wyrażania za jego pomocą wszystkiego, co byśmy chcieli wyrazić" 2 . Kompetencja fonetyczno-fonologiczna, będąca częścią kompetencji językowej, oznacza umiejętność precyzyjnej artykulacji głosek występujących w danym języku, a także zdolność „(...) identyfikacji fonemów i rozpoznawania zbudowanych z nich jednostek wyższego rzędu"3. Jej nabywanie odbywa się etapami, a biologiczne uwarunkowania sięgają okresu prenatalnego, kiedy kształtuje się mózg, płuca, krtań, narządy zmysłów oraz aparat artykulacyjny (jama ustna, nosowa, gardłowa). Przedjęzykowy etap rozwoju mowy, trwający od urodzenia do pierwszego roku życia, stanowi swoisty trening zarówno narządów artykulacyjnych, jak i percepcji słuchowej. Wówczas niemowlę przygotowuje się do wypowiadania i rozpoznawania dźwięków mowy. Dziecko nabywa umiejętności językowe (w tym fonetyczno-fonologiczne), przechodząc przez wszystkie etapy rozwoju mowy, ale czyni to we własnym tempie ${ }^{4}$. To czy i kiedy osiągnie dany etap, zależy od jego

${ }^{1}$ J. Porayski-Pomsta, O rozwoju mowy dziecka. Dwa studia, Dom wydawniczy Elipsa, Warszawa 2015, s. 21.

2 E. Łuczyński, Mowa a język. Podstawy językowe neurologopedii, [w:] Podstawy neurologopedii. Podręcznik akademicki, red. T. Gałkowski, E. Szeląg, G. Jastrzębowska, Wyd. Uniwersytetu Opolskiego, Opole 2005, s. 39.

3 Ibidem, s. 39.

${ }^{4}$ J. Porayski-Pomsta, Zagadnienia periodyzacji mowy dziecka, „Logopeda” 2009, nr 1(7), s. 10. 
stanu biologicznego, psychicznego oraz od otoczenia (środowiska społecznego), w jakim się wychowuje.

Rozpatrując rozwój kompetencji fonetyczno-fonologicznej, należy zwrócić uwagę na współzależność percepcji i ekspresji dźwięków mowy oraz podkreślić, że umiejętności percepcyjne wyprzedzają sprawność artykulacyjną. Według Piotry Łobacz, dziecko w wieku 3-4 lat jest w stanie słuchowo identyfikować „prawie kompletny inwentarz fonemów" 5 . Autorka podkreśla, że opanowanie artykulacji, czyli umiejętności realizacji najtrudniejszych głosek zgodnie $\mathrm{z}$ normą, trwa do wieku wczesnoszkolnego ${ }^{6}$. W praktyce logopedycznej przyjęto, że dziecko siedmioletnie powinno poprawnie wypowiadać wszystkie głoski języka polskiego. To doprecyzowanie jest istotne, gdyż prawidłowy rozwój mowy (w tym prawidłowa wymowa) jest jednym $z$ warunków powodzenia $w$ nauce szkolnej i satysfakcjonującego uczestnictwa w grupie rówieśniczej.

Czynniki powodujące zaburzenia artykulacji mogą zadziałać na poszczególnych etapach rozwoju kompetencji fonetyczno-fonologicznej, ale także po opanowaniu inwentarza fonemów i ich głoskowych realizacji, a więc u starszych dzieci, młodzieży, osób dorosłych czy seniorów. Tak dzieje się w afazji, w której dochodzi do rozpadu systemu językowego, dysartrii (zaburzeniach oddechowofonacyjno-artykulacyjnych, spowodowanych np. udarem czy chorobą Parkinsona), w przypadkach resekcji części aparatu artykula-

${ }^{5}$ P. Łobacz, Prawidłowy rozwój mowy dziecka, [w:] Podstawy neurologopedii. Podręcznik akademicki, red. T. Gałkowski, E. Szeląg, G. Jastrzębowska, Wydawnictwo Uniwersytetu Opolskiego, Opole 2005, s. 233.

${ }^{6}$ Ibidem, s. 235. Periodyzację i szczegółową analizę rozwoju fonetycznofonologicznego polskich dzieci znaleźć można w pracach różnych autorów, patrz: P. Smoczyński, Przyswajanie przez dziecko podstaw systemu jezykowego, Zakład im. Ossolińskich, Łódź-Wrocław 1955; M. Zarębina, Kształtowanie się systemu dźwiękowego dziecka, Ossolineum, Wrocław 1965; L. Kaczmarek, Moje dziecko uczy się mowy, Wyd. Lubelskie, Lublin 1988; P. Łobacz, Polska fonologia dziecięca, Energeia, Warszawa 1996; P. Łobacz, Prawidłowy rozwój mowy dziecka, [w:] Podstawy neurologopedii. Podręcznik akademicki, red. T. Gałkowski, E. Szeląg, G. Jastrzębowska, Wydawnictwo Uniwersytetu Opolskiego, Opole 2005, s. 231-268; J. Porayski-Pomsta, O rozwoju mowy dziecka. Dwa studia, Dom wydawniczy Elipsa, Warszawa 2015. 
cyjnego, stanowiącej konieczny etap leczenia onkologicznego, uszkodzeniach aparatu artykulacyjnego wynikających z modnego obecnie piercingu (kolczykowania) tkanek miękkich jamy ustnej, a także w związku ze zmianami w narządzie żucia u osób w wieku senioralnym (utrata zębów, noszenie protezy zębowej, wiotkość podniebienia miękkiego).

\section{Zaburzenia artykulacji jako przejaw nieprawidłowości w rozwoju fonetyczno-fonologicznym}

Zaburzenia artykulacji, nazywane także wadami wymowy, wadami artykulacyjnymi, zaburzeniami w płaszczyźnie segmentalnej, to odstępstwo od zgodnej z normą realizacji fonemu/fonemów, spowodowane niemożnością jego/ich prawidłowej realizacji. Jak podkreśla Danuta Pluta-Wojciechowska, "głoska wadliwa jest dowodem występowania jakichś trudności w normatywnej realizacji fonemu"7. Do wad wymowy nie zalicza się regionalizmów i dialektyzmów fonetycznych, które są zgodne z ogólnopolską i/lub lokalną normą językową ${ }^{8}$ oraz błędów wymowy będących rezultatem niewiedzy lub złego przyzwyczajenia mówiącego, przy zachowanych możliwościach wypowiedzenia dźwięku, a także tzw. dziecięcych artykulacji ${ }^{9}$, które są efektem nieukończonego procesu rozwoju głoskowo-fonemowego, przekształcających się samoistnie w prawidłowe realizacje $\mathrm{w}$ miarę fizycznego i psychicznego rozwoju dziecka. Ocena, czy dana realizacja fonemu jest patologiczna, czy też wynika z braku dojrzałości procesów percepcyjno-realizacyjnych,

${ }^{7}$ D. Pluta Wojciechowska, Dyslalia obwodowa. Diagnoza, i terapia logopedyczna wybranych form zaburzeń, Wydawnictwo Ergo-Sum, Bytom 2017, s. 85.

${ }^{8}$ I. Jaros, Trzi krziwe krzyże - cecha wymowy, btąd wymowy czy wada wymowy, [w:] Wspótczesne tendencje w diagnozie i terapii logopedycznej, red. D. Pluta-Wojciechowska, B. Sambor, Harmonia Universlais, Gdańsk 2017, s. 100.

${ }^{9}$ B. Ostapiuk, Standard postępowania logopedycznego w dyslalii ankyloglosyjnej, „Logopedia” 2008, t 37, s. 143; G. Demelowa, Minimum logopedyczne nauczyciela przedszkola, Wyd. Szkolne i Pedagogiczne, Warszawa 1994, s. 31. 
nie jest sprawą jednoznaczną ze względu na podobieństwo objawów. „Wadliwe artykulacje” od „dziecięcych artykulacji” różni odmienny mechanizm ich powstania, co należy uwzględnić w procesie diagnostycznym.

Wady wymowy mogą stanowić izolowany problem lub być objawem innych zaburzeń mowy. Nienormatywne realizacje fonemów stwierdza się, np. u osób z wadą słuchu, niepełnosprawnością intelektualną, afazją, dysartrią czy też specyficznymi zaburzeniami rozwoju języka (SLI). U tych pacjentów nieprawidłowości przejawiają się we wszystkich podsystemach języka: fonologicznym, morfologicznym, syntaktycznym, leksykalnym.

Według Gerharda Böhme przyczyny wad wymowy pokrywają się $\mathrm{w}$ zasadzie $\mathrm{z}$ etiologią zaburzeń mowy ${ }^{10}$. Wśród czynników prowadzących do ich powstania wymienia się: zaburzenia słuchu i wzroku, niepełnosprawność intelektualną, uszkodzenia i dysfunkcje układu nerwowego, nieprawidłową budowę oraz wadliwe funkcjonowanie aparatu oddechowego, fonacyjnego i artykulacyjnego. Niekorzystne warunki środowiskowe (brak stymulacji ze strony otoczenia i nieprawidłowe wzorce) także mogą utrudniać kształtowanie się komunikacji językowej, w tym kompetencji fonetyczno-fonologicznej.

Zaburzenia artykulacji zalicza się do najczęściej występujących nieprawidłowości $\mathrm{w}$ rozwoju mowy u dzieci. Statystyki potwierdzają dużą skalę problemu. Badania przeprowadzone przez Grażynę Jastrzębowską na początku lat 90. XX w. wśród 575 uczniów klas zerowych i pierwszych z województwa opolskiego wykazały obecność wad wymowy u $18 \%$ dzieci11. Wyniki prezentowane przez innych badaczy są bardziej alarmujące. Przesiewowe badania logopedyczne prowadzone w aglomeracji śląskiej przez różne autorki

${ }^{10}$ G. Bóhme, Sprach-Sprech-Stimm und Schlucströngen, Urban-Fiscer, MünchenJena 2003.

11 G. Jastrzębowska, Stan i perspektywy opieki logopedycznej w Polsce, [w:] Logopedia. Pytania i odpowiedzi. Podręcznik akademicki. Interdyscyplinarne podstawy logopedii. T. 1, red. T. Gałkowski, G. Jastrzębowska, Wyd. Uniwersytetu Opolskiego, Opole 2003, s. 38. 
dowodzą, że wskaźnik dzieci w wieku przedszkolnym i wczesnoszkolnym z zaburzeniami artykulacji waha się od $29,4 \%$ do $56,8 \%{ }^{12}$. Otrzymane dane korespondują z tymi uzyskanymi w $2016 \mathrm{r}$. przez logopedów z Zakładu Dialektologii Polskiej i Logopedii Uniwersytetu Łódzkiego, którzy realizowali badania przesiewowe uczniów klas I-III jednej ze szkół podstawowych na terenie Łodzi. Na 150 przebadanych dzieci wadliwą realizację fonemów odnotowano u 71 uczniów, co stanowi $47 \% 13$. Z badań przeprowadzonych wśród 2012 dzieci w wieku przedszkolnym z Zielonej Góry i województwa lubuskiego wynika, że zaburzenia artykulacyjne występują u prawie $70 \%$ przedszkolaków ${ }^{14}$.

Przedstawione wyniki badań potwierdzają konieczność podjęcia zdecydowanych działań w związku z dużą liczbą dzieci z wadami wymowy. Ponieważ konsekwencjami zaburzeń artykulacyjnych mogą być problemy w nauce, trudności natury emocjonalnej i społecznej, ważne jest jak najwcześniejsze podjęcie działań zapobiegających powstaniu wad wymowy, a w sytuacjach, kiedy jest to niemożliwe (np. w przypadku wad genetycznych), wczesna diagnoza i terapia logopedyczna.

$12 \mathrm{Z}$ badań Iwony Michalak-Widery wynika, że wady wymowy są obecne u 48\% diagnozowanych przez autorkę uczniów klas pierwszych z terenu Katowic; patrz: I. Michalak-Widera, Zaburzenia dyslaliczne u dzieci realizujących edukację elementarna - doniesienia z badań, „Śląskie Wiadomości Logopedyczne” 2004, nr 7, s. 30; Joanna Trzaskalik wykazała obecność wad wymowy u 55\% katowickich sześciolatków; patrz: J. Trzaskalik, O konieczności badań nad wpływem chorób układu oddechowego na wady wymowy u dzieci w województwie katowickim, [w:] Effata - Otwarcie. Logopedia jako nauka interdyscyplinarna i stosowana, red. I. Nowakowska-Kempna, Uniwersytet Śląski, Katowice 1998, s. 245; Z danych przedstawionych przez Katarzynę Węsierską wynika, że wśród badanych przez autorkę dzieci w wieku 3-6 lat z Katowic wskaźnik nieprawidłowości w zakresie mowy, w tym wady wymowy w poszczególnych grupach wiekowych waha się od 29,4\% do 56,8\%; patrz: K. Węsierska, Opieka logopedyczna w przedszkolu. Profilaktyka - diagnoza - terapia, Wydawnictwo Edukacyjne AKAPIT, Toruń 2013, s. 166.

13 E. Gacka, M. Kaźmierczak, Przesiewowe badania mowy jako przykład działań z zakresu profilaktyki logopedycznej, „Logopaedica Lodziensia” 2017, nr 1, s. 39.

${ }_{14}$ M. Rządzka, Warunki prawidłowego rozwoju mowy dziecka, online: docplayer. pl/429465-warunki-prawidlowego-rozwoju-mowy-dziecka.html [dostęp: 29.11. 2017]. 


\section{Zapobieganie wadom wymowy na wczesnych etapach życia dziecka}

Profilaktyka to jeden z obszarów działań logopedów. Jej celem jest zapobieganie zaburzeniom mowy, promowanie wiedzy o rozwoju mowy i jej deficytach, a także wczesna interwencja - wczesne wykrycie nieprawidłowości w zakresie komunikacji językowej po to, by rozpocząć oddziaływania terapeutyczne, nie dopuszczając do utrwalania się negatywnych konsekwencji zaburzeń mowy. Ewa Małgorzata Skorek definiuje profilaktykę logopedyczną jako

całokształt form organizacyjnych, treści, metod, zasad i środków tworzących spójną strukturę służącą do zapobiegania - po pierwsze - zaburzonej zdolności komunikacyjnej ${ }^{15}$ człowieka uwarunkowanej biologicznie i/lub środowiskowo oraz po drugie - skutkom zaburzonej zdolności komunikacyjnej dla funkcjonowania człowieka ${ }^{16}$.

W logopedii (podobnie jak w medycynie) wyróżnia się trzy poziomy profilaktyki logopedycznej: pierwszo, drugo i trzeciorzędową ${ }^{17}$. Celem profilaktyki I stopnia (pierwszorzędowej) jest zapobieganie zaburzeniom mowy i głosu poprzez upowszechnianie wiedzy logopedycznej, np. informacji na temat warunków sprzyjających prawidłowemu rozwojowi mowy, prawidłowej emisji głosu albo

15 Określeniem „zaburzona zdolność komunikacyjna” (ZZK) posługują się w swoich opracowaniach między innymi: G. Gunia i V. Lechta, patrz: Wprowadzenie do logopedii, red. G. Gunia, V. Lechta, Oficyna Wydawnicza „Impuls”, Kraków 2011, a także E.M. Skorek, patrz: Wielowymiarowość przestrzeni profilaktyki logopedycznej, red. E.M. Skorek, Uniwersytet Zielonogórski, Zielona Góra 2017. Termin ten jest traktowany synonimicznie do „zaburzeń mowy” czy „zaburzeń komunikacji językowej”.

16 E.M. Skorek, Profilaktyka logopedyczna-poziomy i strategie, [w:] Wielowymiarowość przestrzeni profilaktyki logopedycznej, red. E.M. Skorek, Uniwersytet Zielonogórski, Zielona Góra 2017, s. 51.

${ }^{17}$ Ibidem, s. 53-69; K. Węsierska, Profilaktyka logopedyczna w ujęciu systemowym, [w:] Profilaktyka logopedyczna w praktyce edukacyjnej, red. K. Węsierska, t. 1, Wydawnictwo Uniwersytetu Śląskiego, Katowice 2012; G. Gunia, Koncepcja i organizacja opieki logopedycznej w Polsce, [w:] Wprowadzenie do logopedii, red. G. Gunia, V. Lechta, Oficyna Wydawnicza Impuls, Kraków 2011, s. 58-59. 
propagowanie zasad efektywnej komunikacji. Odbiorcą tych treści jest ogół populacji. Profilaktyka II stopnia (drugorzędowa) to wczesne wykrycie zaburzonej zdolności komunikacyjnej i rozpoznanie patologii głosu - działania obejmujące grupy ryzyka, a więc np. dzieci urodzone przedwcześnie, te z zespołami genetycznymi, osoby zawodowo posługujące się głosem. Wczesna identyfikacja nieprawidłowości umożliwia podjęcie działań terapeutycznych w czasie optymalnym dla efektów terapii. Profilaktyka III stopnia to łagodzenie negatywnych skutków już zdiagnozowanych problemów w zakresie komunikacji językowej, a więc działania skierowane do pacjentów "logopedycznych” i ich rodzin, np. wzmacnianie poczucia wartości u dzieci z zaburzeniami mowy/wymowy, przeciwdziałanie ich izolacji społecznej, wykluczeniu z grupy rówieśniczej, przeciwdziałanie bullyingowi ${ }^{18}$. Obecnie coraz częściej podkreśla się potrzebę takiego rozłożenia akcentów w opiece logopedycznej, aby działaniom profilaktycznym nadać wyższą rangę, zwłaszcza profilaktyce pierwszo- i drugorzędowej.

Przeciwdziałanie zaburzeniom artykulacji to zapewnienie optymalnych warunków dla nabywania kompetencji fonetyczno-fonologicznej, począwszy od chwili narodzin, a także monitorowanie rozwoju dzieci z grup ryzyka. Ponieważ mowa/wymowa rozwija się od urodzenia, to najbardziej racjonalne i uzasadnione jest zapobieganie jej nieprawidłowościom od okresu noworodkowego. Przedmiotem szczególnej troski i uwagi powinny być czynności prymarne (pierwotne) względem mowy (będące jednocześnie pierwotne wobec wymowy), do których zalicza się oddychanie oraz przyjmowanie pokarmów i picie, kształtujące się na bazie odruchów ustno-twarzowych ${ }^{19}$. Jak zaznacza Elżbieta Stecko, orędow-

${ }^{18}$ Bullying to „negatywne fizyczne lub werbalne działania, które charakteryzują się wrogą intencją, powodują negatywne emocje u ofiar, są powtarzalne w czasie oraz charakteryzują się różnicą sił pomiędzy sprawcami a ofiarą", W.M. Craig, D.J. Pepler, Identifying and tragenting risk for involvment In bullyingu and victimization. "Canadian Journal of Psychiatry" 2003, vol. 28, s. 577.

${ }^{19}$ D. Pluta-Wojciechowska, Dyslalia obwodowa. Diagnoza i terapia logopedyczna wybranych form zaburzen, Wyd. Ergo-Sum, Bytom 2017, s. 39. 
niczka i propagatorka wczesnej interwencji logopedycznej, rozwój artykulacji następuje „(..) w oparciu o wzorce ruchów pokarmowych kształtujących się na poziomie ssania, następnie żucia i połykania" 20 . Za dalece niewystarczające należy uznać działania, których adresatami są dzieci przedszkolne, a polegające na prowadzeniu ćwiczeń słuchowych, oddechowych i usprawniających pracę narządów artykulacyjnych, do jakich często w praktyce sprowadza się profilaktyka logopedyczna ${ }^{21}$. Dla efektywnego zapobiegania wadom wymowy bardzo ważne jest propagowanie informacji na temat czynników rokowniczych rozwoju wymowy/mowy wśród rodziców, dziadków, opiekunów najmłodszych dzieci - tych w wieku niemowlęcym i poniemowlęcym. Pozwoli to z jednej strony uniknąć niekorzystnych z punku widzenia kształtowania się umiejętności artykulacyjnych sposobów pielęgnacji i opieki nad dzieckiem, a z drugiej strony wskaże, jak stymulować rozwój kompetencji językowej.

W ramach pierwszorzędowej profilaktyki wad wymowy powinny być propagowane treści dotyczące:

1. Korzyści wynikających z naturalnego karmienia. Ssanie piersi angażuje wszystkie mięśnie jamy ustnej dziecka, co sprzyja jej prawidłowemu rozwojowi. Naturalne karmienie dostarcza bodźców przygotowujących do czynności żucia. Przy tym sposobie przyjmowania pokarmu eliminujemy nacisk butelki na dolny wyrostek zębodołowy, co może prowadzić do jego zniekształceń ${ }^{22}$. Naturalne karmienie ułatwia także kształtowanie prawidłowego toru oddechowego przez nos.

${ }^{20}$ E. Stecko, Logopedia matego dziecka, Wydawnictwo@stecko.com.pl, Warszawa 2013, s. 11.

${ }^{21} \mathrm{Na}$ marginesie należy dodać, że w ramach prowadzonej w przedszkolach profilaktyki logopedycznej czasami prowadzone są ćwiczenia wręcz szkodliwe dla części dzieci - tych, u których pozanormatywne realizacje fonemów już wystąpiły, np. ćwiczenia usprawniające pracę języka, a polegające na oblizywaniu warg są niewskazane w przypadkach seplenienia międzyzębowego.

${ }_{22} \mathrm{M}$. Borkowska, Usprawnianie czynności karmienia u dzieci z mózgowym porażeniem, [w:] ABC rehabilitacji dzieci. Mózgowe porażenie dziecięce, red. M. Borkowska, T. 2, Wydawnictwo Pelikan, Warszawa 1989, s. 92. 
2. Znaczenia odpowiedniej pozycji dziecka $\mathrm{w}$ trakcie karmienia (naturalnego, jak i przez butelkę), z możliwością kontroli całego ciała, zwłaszcza głowy i żuchwy. Według Pawła Zawitkowskiego ${ }^{23}$ właściwa pozycja zapewnia dziecku prawidłowy tor oddychania, normatywne napięcie mięśniowe $\mathrm{w}$ całym ciele, w tym szyi i twarzy, oraz należyte ustawienie głowy względem ciała, co ułatwia połykanie. Odpowiedni sposób podawania butelki w linii środkowej (a nie bokiem) zapobiega asymetrycznemu ułożeniu ciała niemowlęcia. Specjaliści podkreślają znaczenie prawidłowych wzorców posturalno-motorycznych dla funkcjonowania aparatu orofacjalnego i mówienia ${ }^{24}$.

3. Należytego doboru akcesoriów w przypadku konieczności karmienia butelką. Kształt smoczka powinien być zbliżony do naturalnego kształtu brodawki sutkowej, jego rozmiar dostosowany do wieku niemowlęcia, a wielkość otworów w smoczku powinna pozwalać na swobodny przepływ mleka, bez zachłystywania się dziecka nadmiarem pokarmu. Ważne jest także odpowiednie ustawienie butelki (prawie prostopadle do ust dziecka), które wymusza doprzedni ruch żuchwy 25 , a tym samym zapobiega utrwaleniu fizjologicznego tyłożuchwia, z którym noworodek przychodzi na świat. Należy też pamiętać, że zbyt długie podawanie pokarmu przez butelkę ze smoczkiem może powodować wady zgryzu oraz sprzyjać kształtowaniu się podniebienia gotyckiego ${ }^{26}$. Karmienie butelką przy braku należytej higieny może też prowadzić do rozwoju tzw. próchnicy butelkowej i przedwczesnej utraty zębów mlecznych.

23 P. Zawitkowski, Wczesna stymulacja rozwoju psychoruchowego dzieci urodzonych przedwcześnie, [w:] Noworodek przedwcześnie urodzony - pierwsze lata życia, red. M.K. Kornacka M.K., Wydawnictwo Lekarskie PZWL, Warszawa 2003, s. 79.

${ }^{24}$ M. Matyja, I. Doroniewicz, Neurorozwojowe podstawy rozwoju mowy $i$ terapii, [w:] Wczesna interwencja logopedyczna, red. K. Kaczorowska-Bray, S. Milewski, Harmonia Universalis, Gdańsk 2016, s. 57.

${ }^{25}$ I. Karłowska, Profilaktyka i oświata zdrowotna, [w:] Zarys wspótczesnej ortodoncji. Podręcznik dla studentów i lekarzy dentystów, red. I Karłowska, Wydawnictwo Lekarskie PZWL, Warszawa 2008, s. 315.

${ }^{26}$ G. Śmiech-Słomkowska, W. Rytlowa, Wybrane zagadnienia z profilaktyki $i$ wczesnego leczenia ortodontycznego. Med. Tour Press International, Warszawa 1993, s. 16. 
4. Konieczności przestrzegania terminarza wprowadzania pokarmów (podawanie pokarmów łyżeczką od około czwartego miesiąca życia ${ }^{27}$ - jako dodatkowy sposób karmienia, nauka picia z kubeczka, wprowadzanie pokarmów o stałej konsystencji). Zaleca się podawanie np. biszkoptów, chleba w okresie wyrzynania się siekaczy, czyli od około szóstego miesiąca życia ${ }^{28}$. W drugim półroczu życia rekomenduje się stopniowe wprowadzanie pokarmów stałych i sukcesywne ograniczanie posiłków w formie papek. Długotrwałe spożywanie produktów miksowanych utrudnia rozwój odgryzania, żucia, gryzienia. Naukę picia z kubeczka można rozpocząć wówczas, gdy dziecko opanuje umiejętność pobierania pokarmu z łyżeczki. Należy też pamiętać o zachowaniu właściwej pozycji podczas nauki picia - bez odchylenia głowy do tyłu.

5. Konieczności dbania o higienę jamy ustnej już od okresu niemowlęcego i udziału w regularnych kontrolach stomatologicznych. W przypadku nieprawidłowości zgryzowych wskazana jest wczesna konsultacja i leczenie ortodontyczne.

6. Znaczenia właściwego sposobu ułożenia dziecka podczas snu/leżenia w łóżeczku czy wózku. Zalecane jest płaskie ułożenie, z główką na niewielkiej poduszce, co jest korzystne dla prawidłowego kształtowania się narządu żucia.

7. Konieczności dbania o prawidłowy tor oddychania dziecka (przez nos). W sytuacji uporczywego oddychania przez usta wskazana jest konsultacja z laryngologiem. Organiczne przyczyny oddy-

27 Porównaj: I. Karłowska, Profilaktyka i oświata zdrowotna, [w:] Zarys wspótczesnej ortodoncji, red. I. Karłowska, wyd. Lekarskie PZWL, Warszawa 2008, s. 315; Polskie Towarzystwo Gastroenterologii, Hepatologii i Żywienia Dzieci rekomenduje wyłączne karmienie piersią do 6. m. ż. ze względu na właściwości odżywcze mleka matki. Porównaj: H. Szajewska i in., Karmienie piersią. Stanowisko Polskiego Towarzystwa Gastroenterologii, Hepatologii i Żywienia Dzieci. „Pediatria”, T. 13, s. 9. Ortodonci i logopedzi podkreślają, że wprowadzenie karmienia łyżeczką od około $4 \mathrm{~m}$. ż. stanowi istotny element treningu przygotowującego do mówienia, przede wszystkim wypowiadania głosek wargowych; zbieranie pokarmu z łyżeczki wymaga większej aktywności warg, niż dzieje się to podczas ssania.

${ }^{28}$ G. Śmiech-Słomkowska, W. Rytlowa, Wybrane zagadnienia z profilaktyki i wczesnego leczenia ortodontycznego. Med. Tour Press International, Warszawa 1993, s. 19. 
chania torem ustnym wymagają interwencji medycznej. Jeżeli przyczyną wadliwego toru oddychania jest nawyk, zaleca się domykanie ust dziecka, np. w czasie snu, bierne lub czynne ćwiczenia zwiększające napięcie mięśnia okrężnego warg. Długotrwałe oddychanie ustami „(...) prowadzi do zmian w kościach twarzy, głównie szczęki, oraz zmian w klatce piersiowej"29. Taki sposób oddychania powoduje powstawanie tzw. gotyckiego podniebienia, wad zgryzu, a w konsekwencji wad artykulacji.

8. Szkodliwości parafunkcji (czynności nietypowych, nawyków), takich jak: ssanie smoczka, palca, błądzenie językiem po wargach itd., które mogą przyczynić się do powstania wad artykulacji i nieprawidłowości zgryzowych.

9. Dbałości o prawidłowy stan słuchu - konieczność pilnej konsultacji z audiologiem bądź laryngologiem $\mathrm{w}$ przypadku pojawienia się niepokojących objawów, takich jak: brak reakcji dziecka na dźwięki z otoczenia, pogorszenie dotychczas prawidłowego stanu słuchu, uporczywe i nawracające infekcje górnych dróg oddechowych, które nieleczone mogą powodować niedosłuch.

10. Wpływu budowy wędzidełka podjęzykowego na jakość czynności pokarmowych i artykulacji. Nawet nieznacznie skrócone wędzidełko podjęzykowe może zaburzać wymowę, a także powodować trudności w ssaniu piersi, żuciu pokarmu ${ }^{30}$.

11. Znaczenia kontaktów werbalnych i niewerbalnych (uśmiech, spojrzenie, gest, mimika) z dzieckiem od pierwszych chwil jego życia. Bardzo istotne jest reagowanie na sygnały wysyłane przez dziecko, co stanowi zachętę do rozwoju przedjęzykowych, a potem językowych form komunikacji. Ważne jest także dostarczanie prawidłowych wzorców mowy/wymowy. Ilość i jakość interakcji z dzieckiem wpływa na stan jego umiejętności językowych (w tym artykulacyjnych) i komunikacyjnych.

${ }^{29}$ S. Iwankiewicz, Otolaryngologia. Podręcznik dla studentów medycyny i stomatologii, PZWL, Warszawa 1991, s. 229.

30 B. Ostapiuk, Postępowanie logopedyczne u osób z dyslalia i ankyloglosją, [w:] Logopedia. Standardy postępowania logopedycznego, red. S. Grabias, J. Panasiuk, T. Woźniak, Wydawnictwo UMCS, Lublin 2015, s. 659. 
12. Znaczenia prawidłowego rozwoju psychoruchowego, społecznego i emocjonalnego dla kształtowania się mowy/wymowy.

13. Możliwości konsultacji logopedycznej w przypadku najmniejszych wątpliwości rodziców lub opiekunów dziecka, dotyczących stanu jego wymowy/mowy, a także jakości poprzedzających ją czynności prymarnych.

W celu zapobiegania zaburzeniom artykulacji, oprócz propagowania informacji o warunkach prawidłowego rozwoju wymowy, ważne są także działania z zakresu profilaktyki drugorzędowej, do których zaliczyć można:

1. Wczesne rozpoznanie dzieci z nieprawidłowymi odruchami ustno-twarzowymi ${ }^{31}$ po to, aby wdrożyć postępowanie terapeutyczne. Konsultacja logopedyczna dzieci z nieprawidłowymi odruchami w obrębie jamy ustnej powinna mieć miejsce już na oddziałach neonatologicznych, noworodkowych.

2. Monitorowanie rozwoju dzieci z grup ryzyka wystąpienia nieprawidłowości w zakresie komunikacji językowej (w tym zaburzeń artykulacji) w ramach wczesnej interwencji. Do podmiotów wczesnej interwencji logopedycznej zalicza się dzieci: z wadami genetycznymi (np. zespołem Pradera-Williego, Downa), z wadami wrodzonymi w obrębie układu nerwowego, $\mathrm{z}$ wadami obwodowego narządu mowy (np. z rozszczepem wargi i podniebienia), a także z zaburzeniami metabolicznymi, uszkodzeniami o.u.n., do których doszło w okresie prenatalnym, okołoporodowym i na bardzo wczesnych etapach rozwoju, z opóźnieniem w rozwoju psychoruchowym, z uszkodzeniami narządów zmysłów, wcześniaki oraz dzieci, u których poszczególne etapy rozwoju mowy nie pojawiają się we właściwym czasie, choć nie stwierdzono u nich innych nieprawidłowości rozwoju ${ }^{32}$.

${ }^{31}$ Do szczególnie istotnych z punktu widzenia rozwoju mowy/wymowy zalicza się odruchy: ssania, połykania, szukania, ryjkowy, wymiotny, kąsania, żucia.

32 E. Gacka, Wczesna interwencja logopedyczna, [w:] W świecie logopedii. Materiaty dydaktyczne, red. A. Podstolec, K. Węsierska, T. 1, Uniwersytet Śląski w Katowicach, Katowice 2012, s. 40-41. 
3. Prowadzenie badań przesiewowych wśród najmłodszych dzieci rozpoczynających edukację przedszkolną (a więc dzieci w wieku od dwóch i pół do trzech lat) ${ }^{33}$.

\section{Zakończenie}

Propagowanie podstaw wiedzy logopedycznej, czyli rozpowszechnianie informacji na temat prawidłowego rozwoju mowy oraz przeciwdziałanie zaburzeniom komunikacji językowej, w tym artykulacji $\mathrm{w}$ ramach profilaktyki II stopnia, powinny stanowić wspólny obszar działań logopedów, lekarzy pediatrów, a także neonatologów, laryngologów, audiologów, ortodontów, fizjoterapeutów, rehabilitantów, pielęgniarek, położnych, pedagogów, psychologów, nauczycieli przedszkoli i opiekunów w żłobkach. Okazją do promowania wiedzy z tego zakresu mogą być zajęcia dla przyszłych rodziców w szkołach rodzenia, spotkania ze specjalistami organizowane w żłobkach, przedszkolach, szkołach, a także wizyty kontrolne, tzw. bilanse zdrowia u pediatry czy badania kontrolne u stomatologa.

\section{Bibliografia}

Borkowska M. Usprawnianie czynności karmienia u dzieci z mózgowym porażeniem, [w:] ABC rehabilitacji dzieci. Mózgowe porażenie dziecięce, red. M. Borkowska, T. 2, Wyd. Pelikan, Warszawa 1989.

Böhme G., Sprach-Sprech-Stimm-Und Schluckströngen. Urban-Fischer. München Jena 2003.

Craig W.M., Pepler D.J., Identifying and tragenting risk for involvment In bullyingu and victimization. "Canadian Journal of Psychiatry" 2003, vol. 28.

Demelowa G., Minimum logopedyczne nauczyciela przedszkola, Wyd. Szkolne i Pedagogiczne, Warszawa 1994.

Gacka E., Kaźmierczak M., Przesiewowe badania mowy jako przykład działań z zakresu profilaktyki logopedycznej, „Logopaedica Lodziensia” 2017, nr 1.

33 Obecnie do przedszkoli przyjmowane są dzieci od 2,5. roku życia. 
Gacka E., Wczesna interwencja logopedyczna, [w:] W świecie logopedii. Materiaty dydaktyczne, red. A. Podstolec, K. Węsierska, T. 1, Uniwersytet Śląski w Katowicach, Katowice 2012.

Gunia G., Koncepcja i organizacja opieki logopedycznej w Polsce, [w:] Wprowadzenie do logopedii, red. G. Gunia, V. Lechta, Oficyna Wydawnicza „Impuls”, Kraków 2011.

Iwankiewicz S., Otolaryngologia. Podręcznik dla studentów medycyny i stomatologii, PZWL, Warszawa 1991.

Jaros I., Trzi krziwe krzyże - cecha wymowy, btąd wymowy czy wada wymowy, [w:] Wspótczesne tendencje $w$ diagnozie $i$ terapii logopedycznej, red. D. PlutaWojciechowska, B. Sambor, Harmonia Universlais, Gdańsk 2017.

Jastrzębowska G., Stan i perspektywy opieki logopedycznej w Polsce, [w:] Logopedia. Pytania i odpowiedzi. Podręcznik akademicki. Interdyscyplinarne podstawy logopedii, red. T. Gałkowski, G. Jastrzębowska, T. 1, Wydawnictwo Uniwersytetu Opolskiego, Opole 2003.

Kaczmarek L., Moje dziecko uczy się mowy, Wyd. Lubelskie, Lublin 1988.

Karłowska I., Profilaktyka i oświata zdrowotna, [w:] Zarys wspótczesnej ortodoncji, red. I. Karłowska, PZWL, Warszawa 2008.

Łobacz P., Prawidłowy rozwój mowy dziecka, [w:] Podstawy neurologopedii. Podręcznik akademicki, red. T. Gałkowski, E. Szeląg, G. Jastrzębowska, Wydawnictwo Uniwersytetu Opolskiego, Opole 2005.

Łobacz P., Polska fonologia dziecięca. Studia fonetyczno-akustyczne. Wyd. Energeia, Warszawa 1996.

Łuczyński E., Mowa a język. Podstawy językowe neurologopedii, [w:] Podstawy neurologopedii. Podręcznik akademicki, red. T. Gałkowski, E. Szeląg, G. Jastrzębowska, Wydawnictwo Uniwersytetu Opolskiego, Opole 2005.

Matyja M., Doroniewicz I., Neurorozwojowe podstawy rozwoju mowy $i$ terapii, [w:] Wczesna interwencja logopedyczna, red. K. Kaczorowska-Bray, S. Milewski, Harmonia Universalis, Gdańsk 2016.

Michalak-Widera I., Zaburzenia dyslaliczne u dzieci realizujących edukacje elementarna doniesienia z badań, „Śląskie Wiadomości Logopedyczne” 2004, nr 7.

Ostapiuk B., Postępowanie logopedyczne u osób z dyslalia $i$ ankyloglosja, [w:] Logopedia. Standardy postępowania logopedycznego, red. S. Grabias, J. Panasiuk, T. Woźniak, Wydawnictwo UMCS, Lublin 2015.

Ostapiuk B., Standard postępowania logopedycznego w dyslalii ankyloglosyjnej, „Logopedia" 2008, t. 37.

Pluta Wojciechowska D., Dyslalia obwodowa. Diagnoza, i terapia logopedyczna wybranych form zaburzeń, Wydawnictwo Ergo-Sum, Bytom 2017.

Porayski-Pomsta J., O rozwoju mowy dziecka. Dwa studia, Dom wydawniczy Elipsa, Warszawa 2015. 
Porayski-Pomsta J., Zagadnienia periodyzacji mowy dziecka, „Logopeda” 2009, nr 1(7), s. 7-31.

Rządzka M., Warunki prawidtowego rozwoju mowy dziecka, online: docplayer.pl/ 429465-warunki-prawidlowego-rozwoju-mowy-dziecka.html [dostęp: 29.11. 2017].

Skorek E.M., Profilaktyka logopedyczna-poziomy i strategie, [w:] Wielowymiarowość przestrzeni profilaktyki logopedycznej, red. E.M. Skorek, Uniwersytet Zielonogórski, Zielona Góra 2017, s. 51-92.

Smoczyński P., Przyswajanie przez dziecko podstaw systemu jezykowego, Zakład im. Ossolińskich, Łódź-Wrocław 1955.

Stecko E., Logopedia małego dziecka, Wydawnictwo@stecko.com.pl, Warszawa 2013.

Szajewska H., Horvath A., Rybak A., Socha P., Karmienie piersia. Stanowisko Polskiego Towarzystwa Gastroenterologii, Hepatologii i Żywienia Dzieci. „Pediatria” 2016, tom 13, s. 9-24.

Śmiech-Słomkowska G., Rytlowa W., Wybrane zagadnienia z profilaktyki $i$ wczesnego leczenia ortodontycznego. Med. Tour Press International, Warszawa 1993.

Trzaskalik J., O konieczności badań nad wptywem chorób uktadu oddechowego na wady wymowy u dzieci w województwie katowickim, [w:] Effata - Otwarcie. Logopedia jako nauka interdyscyplinarna $i$ stosowana, red. I. Nowakowska-Kempna, Uniwersytet Śląski, Katowice 1998, s. 243-350.

Węsierska K., Opieka logopedyczna w przedszkolu. Profilaktyka - diagnoza - terapia, Wydawnictwo Edukacyjne AKAPIT, Torun 2013.

Węsierska K., Profilaktyka logopedyczna w ujęciu systemowym, [w:] Profilaktyka logopedyczna w praktyce edukacyjnej, red. K. Węsierska, t. 1, Wydawnictwo Uniwersytetu Śląskiego, Katowice 2012, s. 25-47.

Wielowymiarowość przestrzeni profilaktyki logopedycznej, red. E.M. Skorek, Uniwersytet Zielonogórski, Zielona Góra 2017.

Wprowadzenie do logopedii red. G. Gunia, V. Lechta, Oficyna Wydawnicza „Impuls”, Kraków 2011.

Zarębina M, Kształtowanie się systemu dźwiękowego dziecka, Ossolineum, Wrocław 1965.

Zawitkowski P., Wczesna stymulacja rozwoju psychoruchowego dzieci urodzonych przedwcześnie, [w:] Noworodek przedwcześnie urodzony - pierwsze lata życia, red. M.K. Kornacka, Wydawnictwo Lekarskie PZWL, Warszawa 2003, s. 68-86. 